\title{
The assessment of groundwater geochemistry of some wells in Rafsanjan plain, Iran
}

\section{Milad Mirzaei Aminiyan a,*, Farzad Mirzaei Aminiyan b, Amin Heydariyan c, Mahmood Reza Sadikhani d}

a Soil Science Department, College of Agriculture, Bu-Ali Sina University, Hamedan, Iran

b Civil Department, College of Engineering, Vali-e-Asr University, Rafsanjan, Iran

c Soil Science Department, College of Agriculture, Vali-e-Asr University, Rafsanjan, Iran

d Soil Science Department, College of Agriculture, Lorestan University, Iran

\section{Article Info}

Received : 03.01.2016

Accepted : 13.02 .2016

\begin{abstract}
Water quality is the critical factor that influence on human health and quantity and quality of grain production in semi-humid and semi-arid area. Groundwater and irrigation water quality play important roles in main production this crop. For this purpose, 94 well water samples were taken from 25 wells and samples analyzed. The results showed that four main types of water were found: $\mathrm{Na}-\mathrm{Cl}, \mathrm{K}-\mathrm{Cl}, \mathrm{Na}-\mathrm{SO}_{4}$, and $\mathrm{K}-$ $\mathrm{SO}_{4}$. It seems that most wells in terms of water quality (salinity and alkalinity) and based on Wilcox diagram have critical status. The analysis suggested that more than $87 \%$ of the well water samples have high values of EC that these values are higher than into critical limit EC value for irrigation water, which may be due to the sandy soils in this area. Most groundwater were relatively unsuitable for irrigation but it could be used by application of correct management such as removing and reducing the ion concentrations of $\mathrm{Cl}^{-}, \mathrm{SO}_{4}{ }^{2-}, \mathrm{Na}^{+}$and total hardness in groundwater and also the concentrated deep groundwater was required treatment to reduce the salinity and sodium hazard. Given that irrigation water quality in this area was relatively unsuitable for most agriculture production but pistachio tree was adapted to this area conditions. The integrated management of groundwater for irrigation is the way to solve water quality issues not only in Rafsanjan area, but also in other arid and semi-arid areas.
\end{abstract}

Keywords: Irrigation, saline, water quality, groundwater, Rafsanjan

\section{Introduction}

Water quality is the critical factor that influences on human health and quantity and quality of grain production in arid and semi-arid areas. Pistachio (Pistacia Vera L.) nuts are an important product of Iran and the USA (the world's first and second producers, respectively), but interest in this species as an alternative to traditional fruit crops is growing in other countries. Rafsanjan has been recognized as one of the largest pistachio production sites, not only in Iran but also worldwide. Rafsanjan area is water scarcity due to general low precipitation, high evaporation and the temporal and spatial distribution of rainfall. The mean of relative moisture is $7.33 \%$. The mean annual precipitation in this area ranged between 97 to more than 100

\footnotetext{
${ }^{*}$ Corresponding author.

Soil Science Department, College of Agriculture, Bu-Ali Sina University, Hamedan, 6517833131 Iran

Tel.: +9834342899351

E-mail address: miladmir67@yahoo.com

e-ISSN: 2147-4249 DOI: http://dx.doi.org/10.18393/ejss.2016.3.221-230
} 
$\mathrm{mm} / \mathrm{yr}$. The ranges of temperature in this area is between $-8^{\circ} \mathrm{c}$ in winter to $43^{\circ} \mathrm{c}$ in summer. Pistachio is a major crop in Rafsanjan area. Pistachio nuts can be grown in an arid and semi-arid climatic conditions and its tolerance to salinity but drought and saline stress are a major cause of yield loss (Behboudian et al., 1986; Goldhamer et al., 1987). The growth season was divided into three phenological stages (Goldhamer, 1995): stage $I$ starts at the beginning of the nut growth and ends when its maximum size is reached; during stage $I I$ the shell hardening takes place and finally, the stage III is the period of kernel growth (Goldhamer, 1995). Two immediate responses to this challenge are the efficient use of irrigation technology and the use of alternative sources of water. In the arid and semi-arid zones, the production of fruits and nuts are fully dependent upon irrigation (Naor, 2006).

The substantial investments associated with orchard establishment can only be justified if production is high and stable throughout the life of the orchard. Therefore, orchards have been developed mostly in lands where irrigation water supply was abundant, even in drought years. Increasing water use efficiency in irrigated agriculture and promoting dry land farming will both play a significant role in maintaining food security (Deng et al., 2006; Ribolzi et al., 2011). Conditions of water quality and quantity are two key factors impacting groundwater utilization for irrigation. Therefore Groundwater and Irrigation water quality play essential role in agricultural practices and particularly in pistachio harvesting. Consider of this area is located in arid and semi-arid climate and there has high evaporation therefore observed saline and alkaline soil and water in this area. Saline groundwater is often found at shallow depth in irrigated areas of arid and semi-arid regions and is associated with problems of soil salinization and land degradation. In saline soil and alkaline soil observed Low hydraulic potential and bad effects of ions such as: $\mathrm{Cl}^{-}, \mathrm{HCO}_{3}{ }^{-}$, Boron and particularly $\mathrm{Na}^{+}$due to increase $\mathrm{Na} / \mathrm{K}, \mathrm{Na} / \mathrm{Ca}, \mathrm{Cl} / \mathrm{NO}_{3}, \mathrm{Mg} / \mathrm{Ca}$ in plant and nonequivalent between nutrient concentration and therefore decrease plant growth (Hosseinifard et al., 2005a; 2005b).

Increase salt concentration in soil and water causing potassium sorption decrease by plant and $\mathrm{K}^{+}$deficiency in plant (Hosseinifard et al., 2010). Groundwater, which contains numerous natural ions and may be polluted by human activities, seriously influences agricultural utilization. Moreover, irrigation water with excessive ions also impacts the environment. For example, the most common ions in groundwater are chloride $\left(\mathrm{Cl}^{-}\right)$and sodium $\left(\mathrm{Na}^{+}\right)$, particularly in coastal aquifers. When water with high $\mathrm{Cl}^{-}$and $\mathrm{Na}^{+}$ concentrations is used for irrigation, many plants suffer from toxicity and retardation growth, resulting in yield reduction (Karaivazoglou et al., 2005; Grieve et al., 2006).

Groundwater quality typically contains a variety of hydrochemical parameters Therefore, the assessment of groundwater used for irrigation subject to hydrochemical parameters should be performed using a multivariate approach (Khan et al., 2006; Jang and Chen, 2009). Improved water management can also help minimize offsite water quality impacts of irrigated production. Irrigated agriculture affects water quality in several ways, including higher chemical-use rates associated with irrigated crop production, increased field salinity and erosion due to applied water, accelerated pollutant transport with drainage flows, degradation due to increased deep percolation to saline formations, and greater in stream pollutant concentrations due to reduced flows. Strategies to improve the Nation's water quality must address the effect of irrigation on surface and ground water bodies (Rogers, 1996; Liu et al., 2009). However groundwater is one of important resource of water supply for irrigation water in arid and semi-arid areas. The objective of this study was to determine irrigation water quality in Rafsanjan area and assay management practices on applied ground water in this area.

\section{Material and Methods}

\section{Description of the study area}

This study was conducted in the commercial orchards in some pistachio growing areas of Rafsanjan. Rafsanjan is an area in southeast Iran (Kerman province), this area located between longitude: 55 , 59', 30"E and latitude $31^{\circ}, 13^{\prime \prime} \mathrm{N}$. The mean annual precipitation of the region is less than $100 \mathrm{~mm}$. The mean annual potential evapotranspiration is more than $3000 \mathrm{~mm}$. Soil moisture and temperature regimes are aridic and thermic, respectively. Groundwater has been used for various purposes, such as drinking, agricultural, domestic, and industrial needs. The most important economic activity of this area is agriculture. In the selected orchards, the common irrigation intervals are about 48 days. 


\section{Sample collection and analysis}

From Twenty five areas in Rafsanjan region, groundwater samples were selected based on the preliminary field survey from Rafsanjan in the Kerman Province, July 2011. The area studied occupies about $135 \mathrm{~km}^{2}$, with a mean altitude of 1,469 m.a.s.l. (Figure 1). Most of these wells supply water for gardening and irrigation. Samples were collected after a pumping time of about $30 \mathrm{~min}$. Samples were analyzed in the laboratory for the major ions employing standard methods. The analyses were carried out within $48 \mathrm{~h}$ of collection. Care was taken that the $\mathrm{pH}$, electrical conductivity (EC), $\mathrm{HCO}_{3}{ }^{-}$, and $\mathrm{Ca}^{2+}$ ions were analyzed within $4 \mathrm{~h}$ of sampling. The $\mathrm{pH}$ and $\mathrm{EC}$ were measured. Calcium $\left(\mathrm{Ca}^{2+}\right)$ and magnesium $\left(\mathrm{Mg}^{2+}\right)$ were determined titrimetric ally using standard EDTA. Chloride $\left(\mathrm{Cl}^{-}\right)$was determined by standard $\mathrm{AgNO}_{3}$ titration method. Carbonate $\left(\mathrm{CO}_{3}{ }^{2-}\right)$ and bicarbonate $\left(\mathrm{HCO}_{3}{ }^{-}\right)$were determined by titration with $\mathrm{HCl}$. Sodium $\left(\mathrm{Na}^{+}\right)$ and potassium $\left(\mathrm{K}^{+}\right)$were measured by flame photometry, sulfate $\left(\mathrm{SO}_{4}{ }^{2-}\right)$ by spectrophotometric turbidimetry. Total dissolved solids (TDS) were computed by multiplying the EC (dS.m $\left.{ }^{-1}\right)$ by a factor of 640 . The alkalinity (sodium) hazard of water is described by the sodium adsorption ratio (SAR) (Hosseinifard and Aminiyan, 2015):

$$
S A R=\frac{N a}{\sqrt{\frac{(C a+M g)}{2}}}
$$

The ionic symbols indicate concentrations of the ions in the water in mill equivalent per liter. Total hardness (TH) of groundwater was calculated using following equation (Sawyer et al., 2003):

$$
\mathrm{TH}\left(\mathrm{mg} \mathrm{CaCO}_{3} / \mathrm{lit}\right)=\left(\mathrm{Ca}^{2+}+\mathrm{Mg}^{2+}\right) \text { meq. } \mathrm{I}^{-1} \times 50
$$
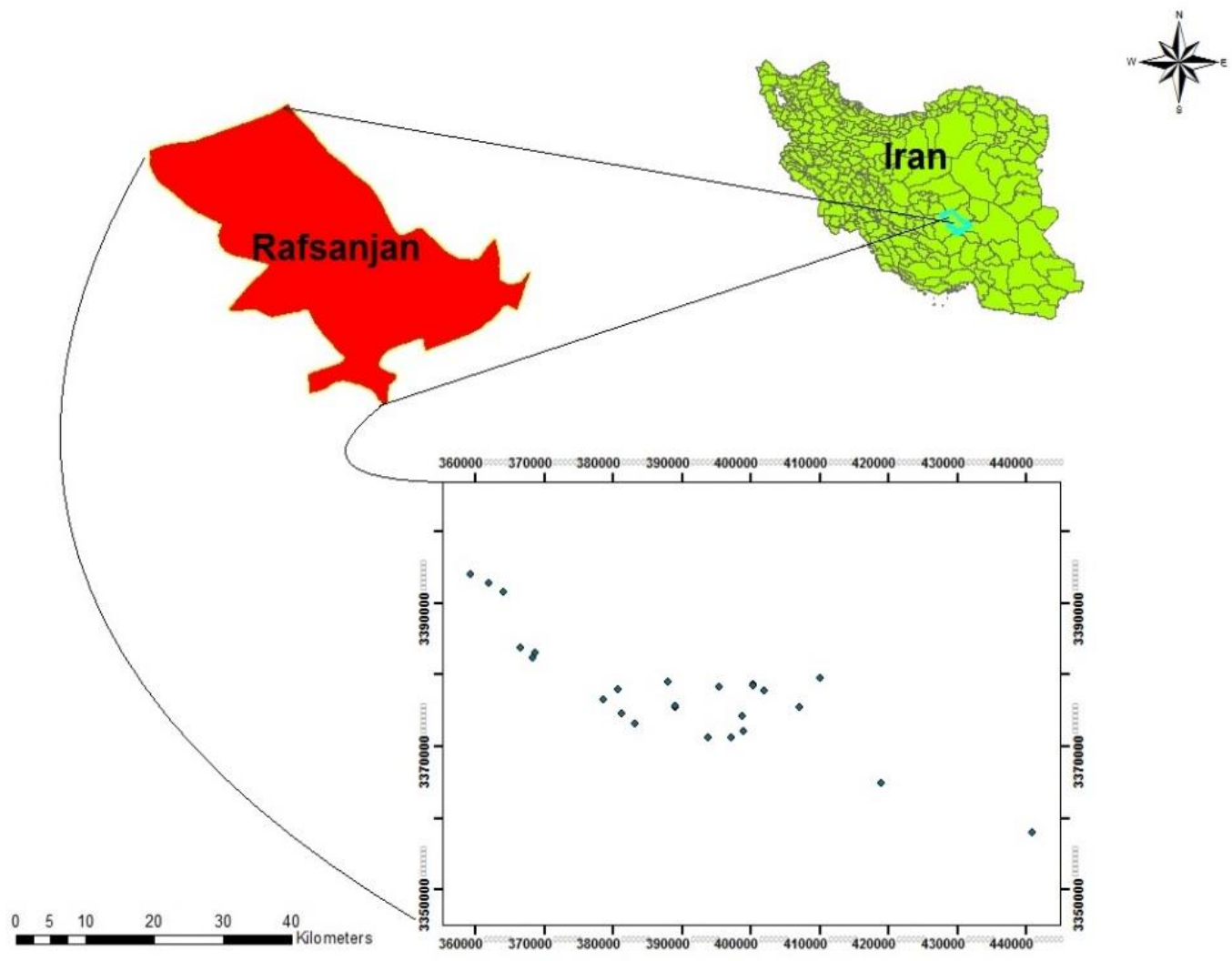

Figure 1. The location of the groundwater sampling wells

\section{Data of statistical analysis}

Statistical analysis and water samples chemical analysis were carried out using SAS (version 9.2), MINITAB (version 14) and Rockworks (version 15) water quality software respectively. Also the GIS map depicted by GS plus (Version 7) software. 


\section{Results and Discussion}

The chemical compositions of the well samples were statistically analyzed and the results are given in. The results showed that concentration of $\mathrm{K}^{+}$and $\mathrm{Na}^{+}$were dominant cations and $\mathrm{Cl}^{-}$and $\mathrm{SO}_{4}{ }^{2-}$ were main anions in water samples (Table 1). Thus, the order of cation abundance is $\mathrm{K}^{+}>\mathrm{Na}^{+}>\mathrm{Ca}^{2+}>\mathrm{Mg}^{2+}$ and the order of anion abundance is $\mathrm{Cl}^{-}>\mathrm{SO}_{4}{ }^{-}>\mathrm{HCO}_{3}{ }^{-}$.

Table 1. Summary statistics of chemical compositions of major ions (mg. $\left.\mathrm{L}^{-1}\right)$ in water samples.

\begin{tabular}{lccccccccccc}
\hline Variable & $\mathbf{N a}$ & $\mathbf{M g}$ & $\mathbf{C a}$ & $\mathbf{K}$ & $\mathbf{C l}$ & $\mathbf{H C O}_{3}$ & $\mathbf{S O}_{4}$ & $\mathbf{p H}$ & $\mathbf{E C}$ & TDS & TH \\
\hline Mean & 732.67 & 177.69 & 351.94 & 967.90 & 1876.41 & 55.00 & 757.69 & 7.51 & 6.64 & 4249.19 & 1620.21 \\
Min & 151.80 & 16.80 & 72.00 & 343.20 & 280.00 & 6.10 & 134.40 & 6.80 & 1.90 & 1216.00 & 330.00 \\
Max & 2417.30 & 864.00 & 1760.00 & 26220.80 & 4987.50 & 146.40 & 4701.60 & 8.40 & 23.90 & 1529.00 & 7375.00 \\
Median & 541.65 & 132.00 & 258.00 & 854.10 & 1400.00 & 48.80 & 516.96 & 7.50 & 4.94 & 3168.00 & 1230.00 \\
$\mathbf{N}^{*}$ & 94 & 94 & 94 & 94 & 94 & 94 & 94 & 94 & 94 & 94 & 94 \\
\hline
\end{tabular}

* N: Total sample

Correlation assessment between dissolved ions in well samples suggested that may found their origin. The ions were correlated together, they have similar origin usually. The results showed that between $\mathrm{Cl}^{-}$and $\mathrm{Ca}^{2+}, \mathrm{Mg}^{2+}$ and $\mathrm{Na}^{+}$there was significant correlation $(\mathrm{r}=0.74),(\mathrm{r}=0.57),(\mathrm{r}=0.46)$ respectively (Figure 2). Therefore the possible origin of these cations may be considered salts such as: $\mathrm{CaCl}_{2}, \mathrm{MgCl}_{2}, \mathrm{KCl}$ and $\mathrm{NaCl}$. Due to have high significant correlation between $\mathrm{Ca}^{2+}$ and $\mathrm{Mg}^{2+}$ cations $(p \leq 0.001)$, perhaps may there was origin such as Dolomite mineral $\left(\mathrm{Ca}, \mathrm{MgCO}_{3}\right)$ for this cations and also there was negative significant correlation between $\mathrm{Cl}^{-}$and $\mathrm{HCO}_{3}{ }^{-}$anions (Table 2).
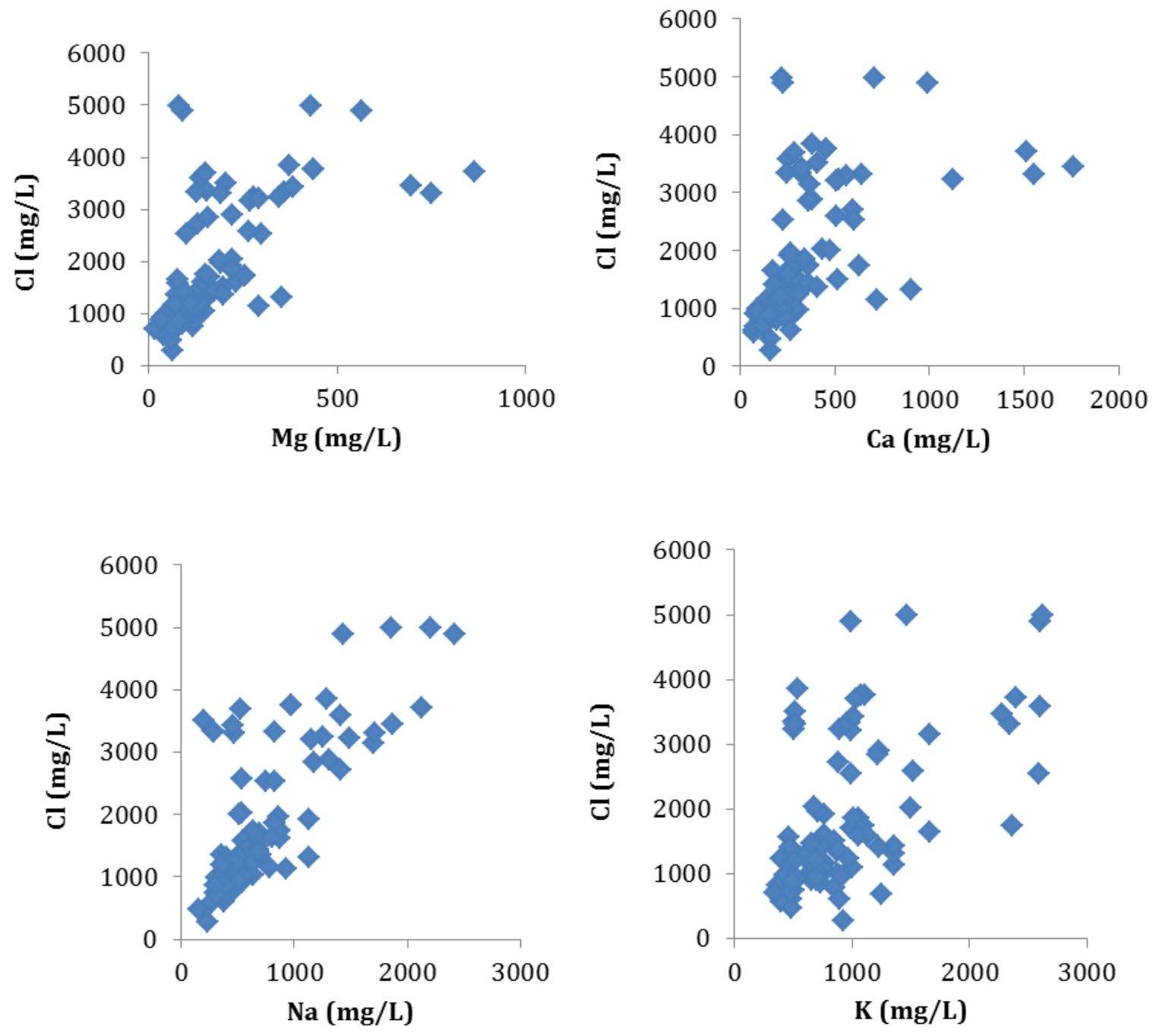

Figure 2. Relationships between the major cations and $\mathrm{Cl}$ anion. 
Table 2. Pearson correlation between hydrochemical characteristics of groundwater samples.

\begin{tabular}{c|cccccccc}
\hline & $\mathbf{N a}$ & $\mathbf{M g}$ & $\mathbf{C a}$ & $\mathbf{C l}$ & $\mathbf{H C O}_{3}$ & $\mathbf{p H}$ & $\mathbf{E C}$ & $\mathbf{S O}_{\mathbf{4}}$ \\
\hline $\mathbf{M g}$ & 0.57 & 1 & & & & & & \\
$\mathbf{C a}$ & 0.53 & 0.89 & 1 & & & & & \\
$\mathbf{C l}$ & 0.74 & 0.57 & 0.46 & 1 & & & & \\
$\mathbf{H C O}$ & -0.18 & -0.13 & -0.12 & -0.22 & 1 & & & \\
$\mathbf{p H}$ & 0.42 & 0.66 & 0.71 & 0.22 & -0.08 & 1 & 1 & 1 \\
$\mathbf{E C}$ & 0.90 & 0.82 & 0.79 & 0.77 & -0.19 & 0.61 & 0.59 & 0.55 \\
$\mathbf{S O}_{4}$ & 0.40 & 0.63 & 0.74 & 0.16 & -0.08 & 0.70 & 0.70 & \\
$\mathbf{K}$ & 0.70 & 0.35 & 0.38 & 0.54 & -0.31 & 0.41 & & \\
\hline
\end{tabular}

Correlation is significant at the 0.01 level (2-tailed)

\section{Piper Diagram}

Based on dominant cations and anions in well water samples, four main types of water were found (Figure 3): $\mathrm{Na}-\mathrm{Cl}, \mathrm{K}-\mathrm{Cl}, \mathrm{Na}-\mathrm{SO}_{4}$, and $\mathrm{K}-\mathrm{SO}_{4}$. This result showed this water types very similar to ocean water and very saline area's water and also result suggested that, non-carbonatic alkaline ions were more than $50 \%$ and alkaline and very acidic ions were dominant in well water samples.

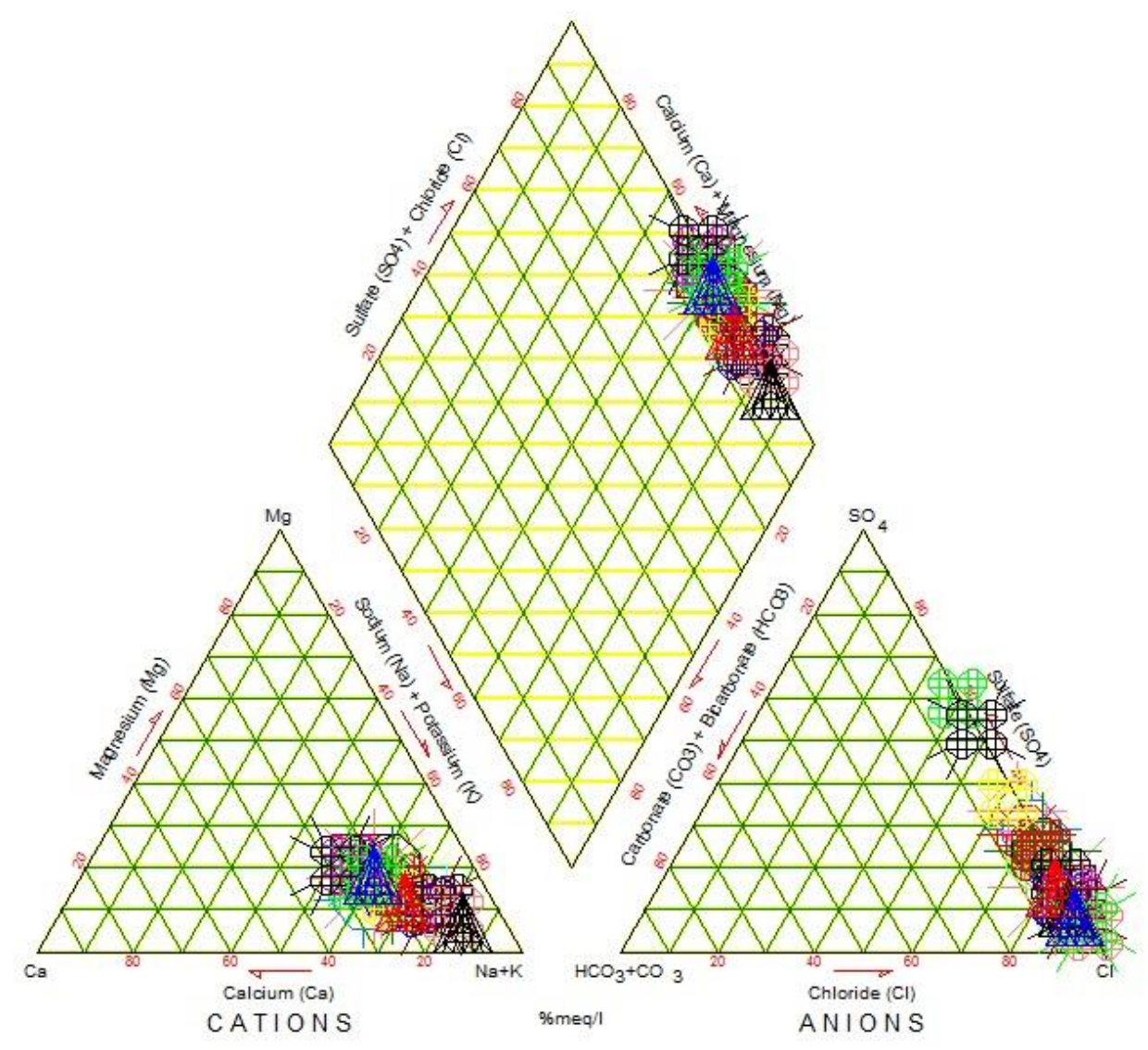

Figure 3. Piper diagram for the well water samples of the studied area

\section{Irrigation water quality}

Salinity is the total amount of inorganic solid material dissolved in any natural water, and water salinization refers to an increase in TDS and overall chemical content of water (Ritcher and Kreitler, 1993). Water that enters to the soil is subject to chemical, physical, and biological changes. Classification of well water based on TDS (Freeze and Cherry, 1979) indicates that primary of the samples are brackish water with TDS ranges from 1216 to 1529 with an average of $4249.19 \mathrm{mg} \mathrm{L}^{-1}$. The analysis suggested that more than eighty-seven percentage of the well water samples have high values of EC that these values are higher than into critical limit EC value for irrigation water (Figure 4), which may be due to the sandy soils in this area (Figure 5). 


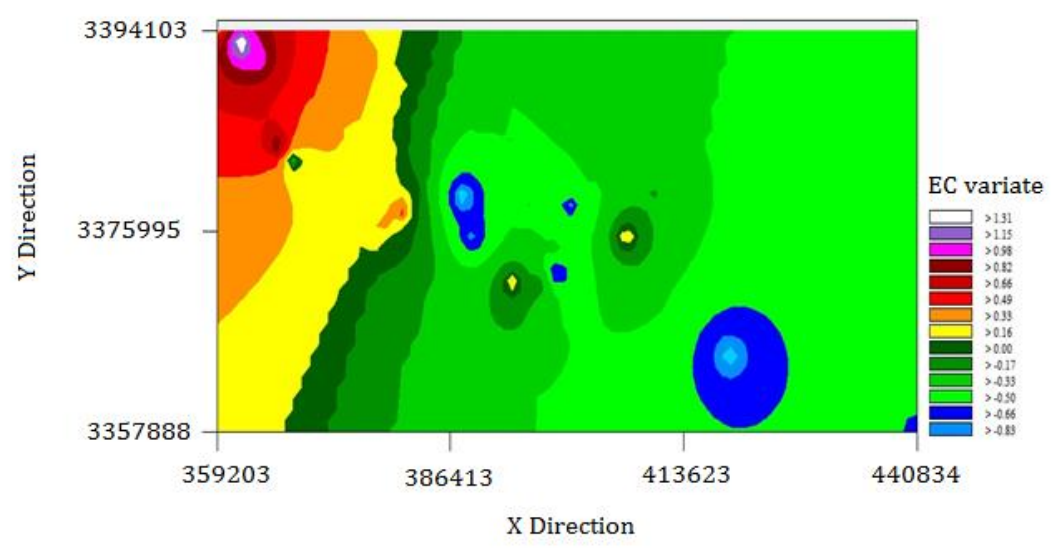

Figure 4. Spatial varibility of EC $(\mathrm{dS} / \mathrm{m})$ in Rafsanjan well water samples

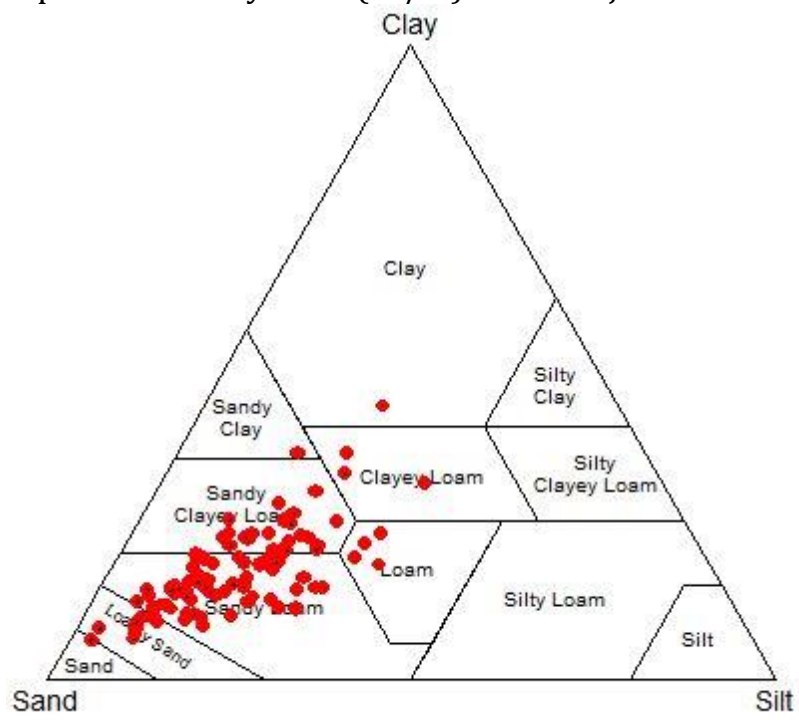

Figure 5. Soil sample texture of studied area.

Hardness of water depends dominantly upon the amounts of divalent metallic cations, of which $\mathrm{Ca}^{2+}$ and $\mathrm{Mg}^{2+}$ are the more abundant in groundwater. The hardness values in well water samples range from 330 to 7375 (mg L-1 $\left.\mathrm{CaCO}_{3}\right)$, the average being $1620.21\left(\mathrm{mg} \mathrm{L}^{-1} \mathrm{CaCO}_{3}\right)$. The most recommended limit of total hardness is $80-100 \mathrm{mg} \mathrm{l}^{-1} \mathrm{CaCO}_{3}$ (Freeze and Cherry, 1979). Well water samples exceeding the limit of 300 ( $\mathrm{mg} \mathrm{L}^{-1} \mathrm{CaCO}_{3}$ ) is considered to be very hard (Sawyer et al., 2003). Therefore most water samples fall in the very hard waters category. Sodium concentration is important when evaluating the suitability of quality water for irrigation. High concentrations of $\mathrm{Na}^{+}$are unfavorable in water because $\mathrm{Na}^{+}$is adsorbed onto the soil cation exchange sites, causing soil aggregates to disperse, reducing its permeability.

The SAR, which indicates the effect of relative cation concentration on $\mathrm{Na}^{+}$accumulation in the soil, is used for evaluating the alkalinity of irrigation water. The calculated SAR ranged from 4.95 to 16.6. In order to identify the availability of waters for irrigation use, The parameters such as electrical conductivity, sodium adsorption ratio (SAR), and percent sodium (Na\%) were estimated to assess the suitability of surface water and groundwater for irrigation purpose. The irrigation waters classification diagrams were used to assess the water quality (Richards, 1954; Wilcox, 1955), (Figure 6). According to this graph, water classes of water samples are mainly (60\%) fall in the category C4-S4, 20\% of water samples fall in C4-S3 and 20\% of water sample fall in C4-S2.

Water samples are located in these categories special management for salinity and alkalinity control may be required, and plants with good salt tolerance should be selected and can be grown. Therefore, based on (Figure 6) the salinity hazard in well water samples is regarded as very high, but the $\mathrm{Na}^{+}$hazard is regarded as high to very high. Given that physiologic and phonologic characteristics of pistachio tree and there is sandy loam dominant soil texture (Figure 5) in this area, pistachio tree is tolerance to salinity and alkalinity condition and it adapted to this area conditions. 


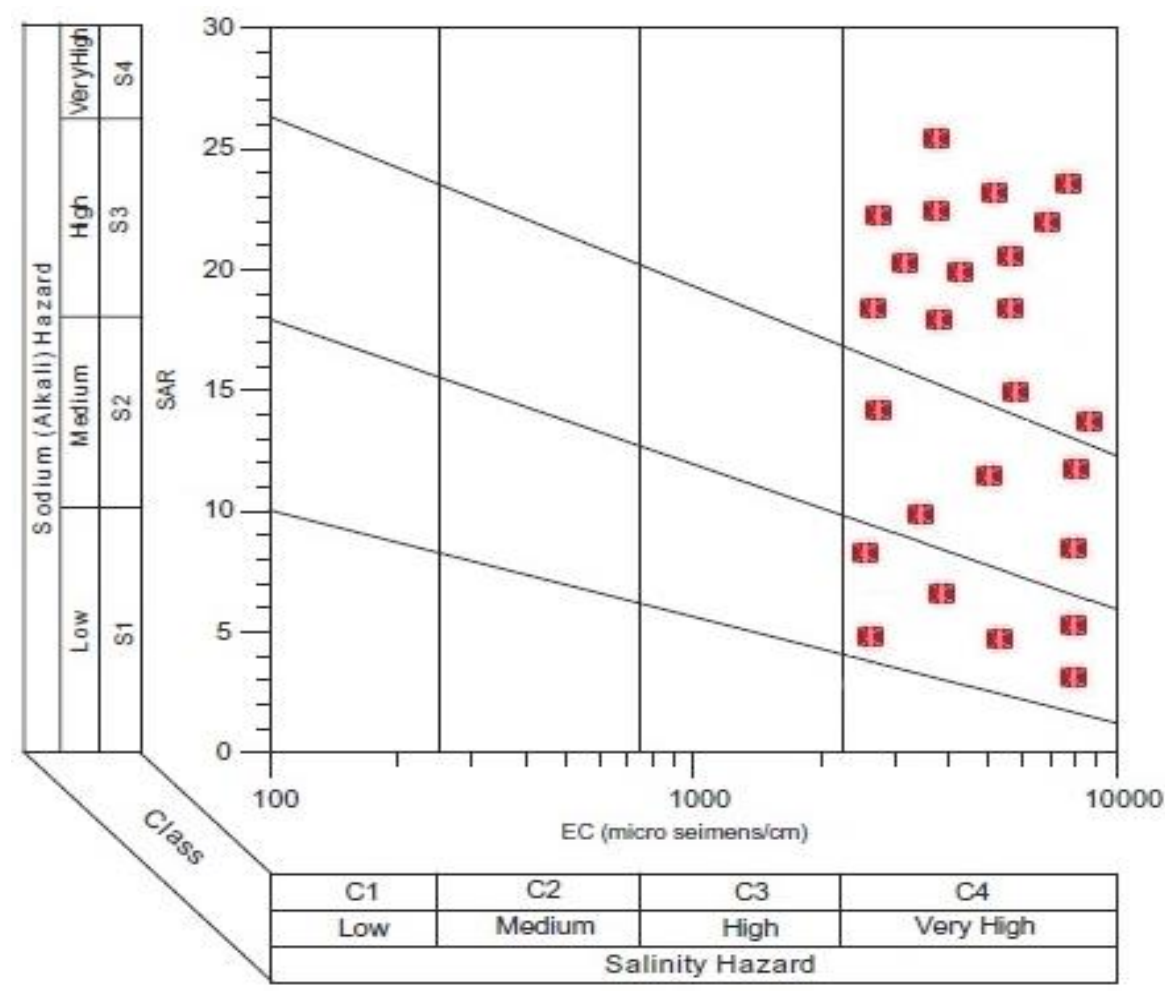

Figure 6. Diagram for irrigation waters classification Wilcox, (1955).

\section{Hierarchical cluster analysis}

Hierarchical cluster analysis (HCA) is used to test water quality data and determine if samples can be grouped into hydrochemical groups. The hierarchical cluster analysis method was used to group water samples into significant different clusters. Two groups were generated from hierarchical cluster analysis (Figure 7). Most of water samples were classified as group (II). In the each group, subareas well water samples had similar hydrochemical characteristics but between group I and group (II) there was different hydrochemical characteristics. Both groups consist of two subgroups.

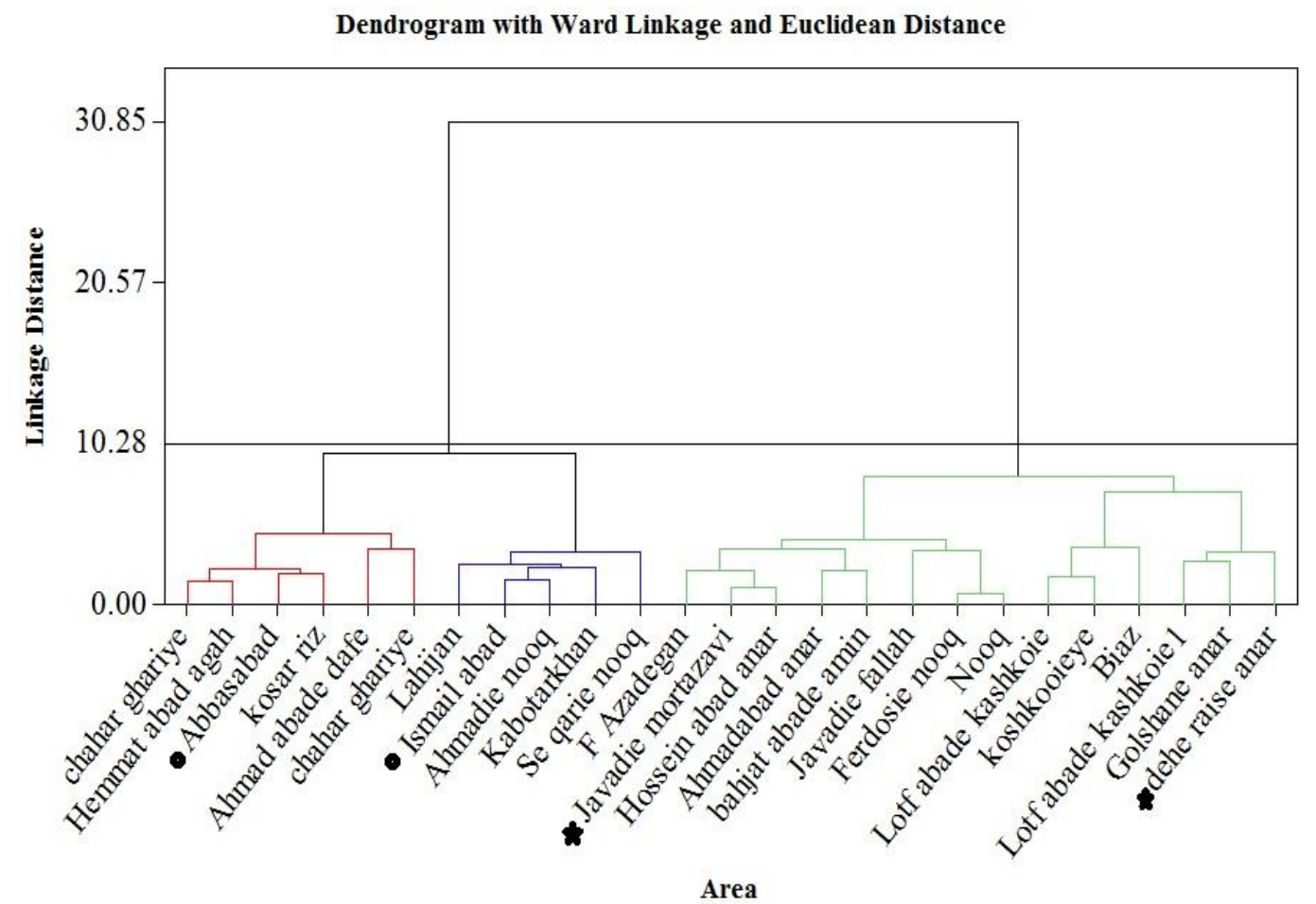

Figure 7. Dendrogram generated from HCA of well water samples chemistry data. 
From each group two subarea selected and stiff diagram was mapped (Figure 8). Stiff diagrams plot milliequivalent concentrations of cations on the left side of the diagram and of anions on the right. Each ion is plotted as a point, and the points are connected to form a polygonal shape. The ions are plotted in a consistent order $\left(\mathrm{Na}+\mathrm{K}\right.$ across from $\mathrm{Cl}$; $\mathrm{Ca}$ across from $\mathrm{HCO}_{3}+\mathrm{CO}_{3} ; \mathrm{Mg}$ across from $\left.\mathrm{SO}_{4}\right)$ so that each polygon becomes that sample's "signature". The greatest polygon was dehe raise anar and smallest polygon was abbasabad. Therefore observed that concentration of cations and anions in dehe raise anar were more than to the other subareas. From subareas selected Abbasabad, Ismail Abad and Javadie Mortazavi are expected that have similar water quality.

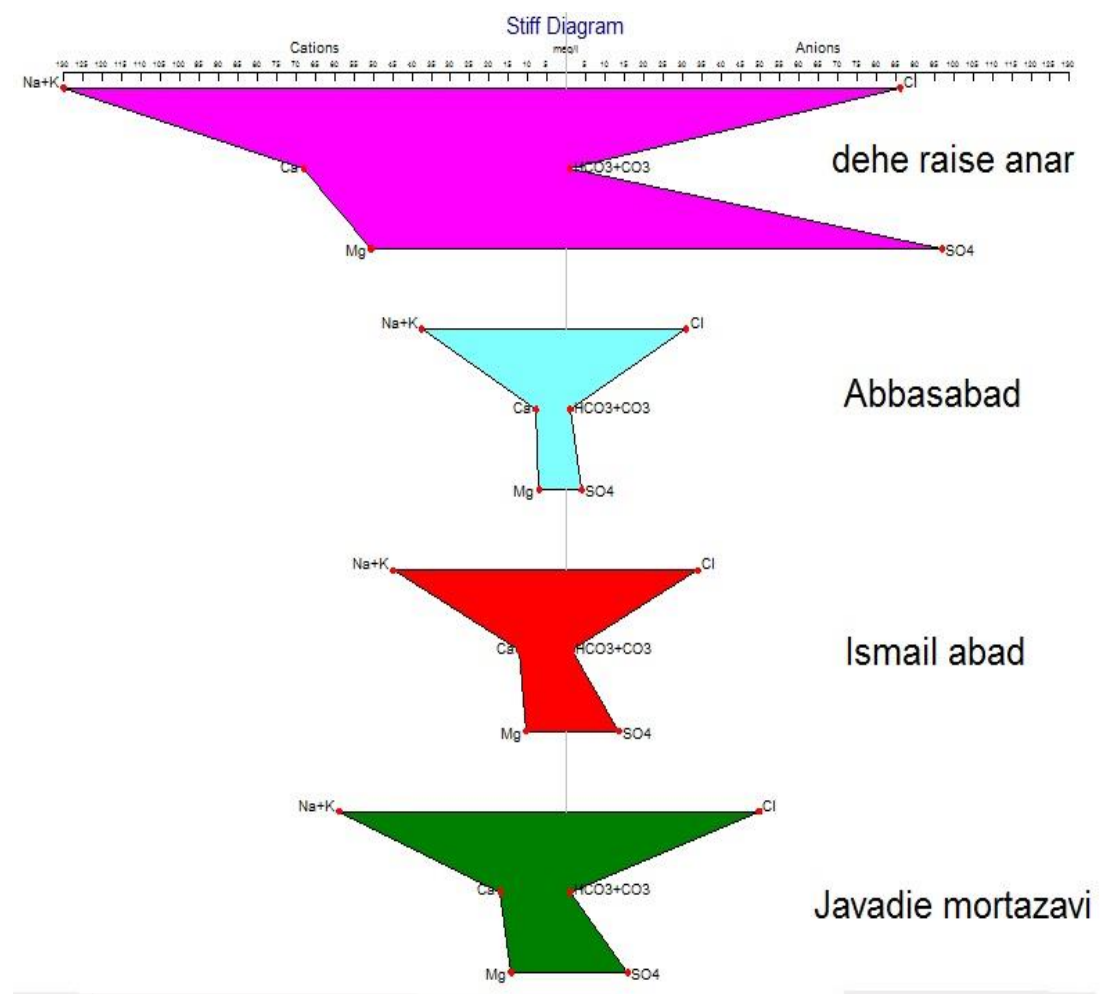

Figure 8. Stiff diagram of subarea from Rafsanjan area

\section{Principal Component Analysis (PCA)}

The multivariate statistical techniques such as principal component analysis (PCA) have widely been used as unbiased method in analysis of water quality data for drawing meaningful information. PCA is a very powerful technique applied to reduce the dimensionality of a data set consisting of a large number of interrelated variables, while retaining as much as possible the variability present in data set. This reduction is achieved by transforming the data set into a new set of variables, the principal components (PCs), which are orthogonal (non-correlated) and are arranged in decreasing order of importance. Mathematically, the PCs are computed from covariance or other cross-product matrix, which describes the dispersion of the multiple measured parameters to obtain eigenvalues and eigenvectors. Principal components are the linear combinations of the original variables and the eigenvectors. The results showed that approximately $82 \%$ of the variation is explained by two main components; thus, the summary data successfully and with high variance is very good (Figure 9).

More assessments can be observed between PC1 with the greatest amount of variance explained is $68 \%$ versus 14\% PC2. As seen in PC1 variables $\mathrm{pH}$ and bicarbonate is placed in front of the other variables measured. So it seems the difference in water quality of wells due to different amounts of $\mathrm{pH}$ and bicarbonate. PC2 has positive relationship with $\mathrm{Na}$ (Eigenvalue: 0.241 ), $\mathrm{K}, \mathrm{Cl}, \mathrm{pH}, \mathrm{TDS}$ and SAR whereas PC2 has negative relationship with the other parameters (Table 3). 


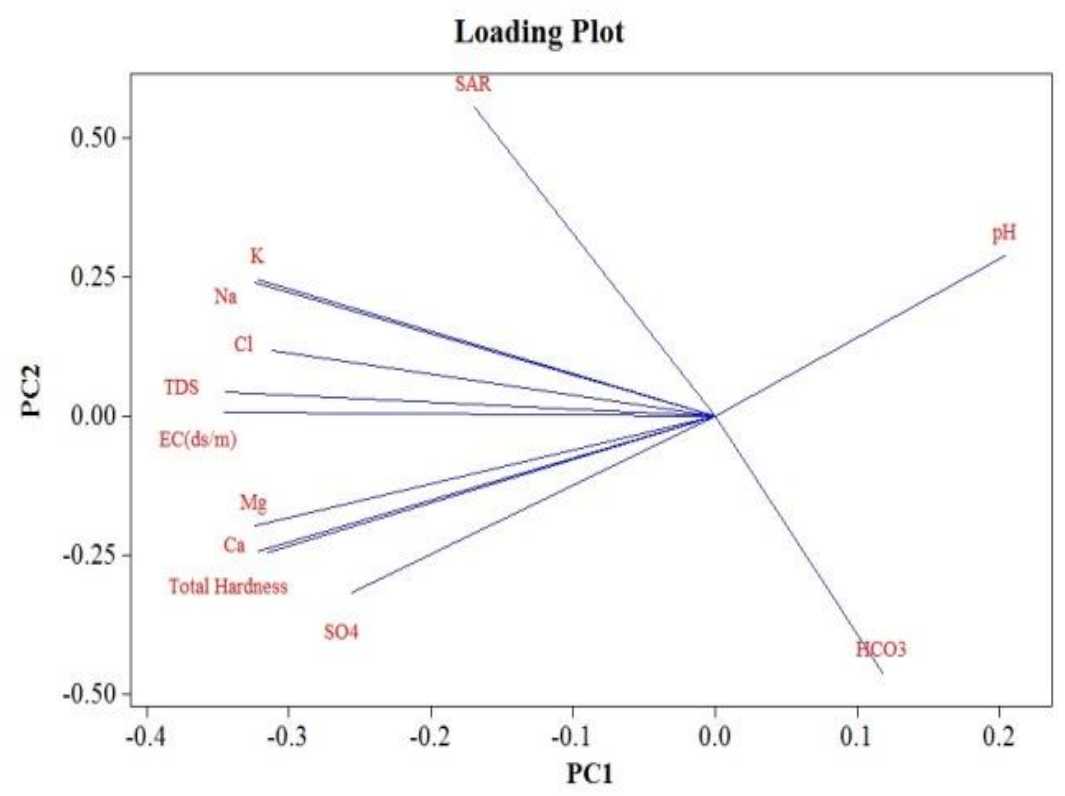

Figure 9. Principal Component Analysis (PCA) loading plot.

Table 3. Relationship PC1 and PC2 with ions and chemical parameters

\begin{tabular}{lcc}
\hline Variable & PC1 & PC2 \\
\hline Na & -0.324 & 0.241 \\
Mg & -0.324 & -0.197 \\
Ca & -0.315 & -0.246 \\
K & -0.321 & 0.247 \\
Cl & -0.311 & 0.119 \\
HCO $_{3}$ & 0.118 & -0.461 \\
SO $_{4}$ & -0.256 & -0.317 \\
pH & 0.204 & 0.290 \\
EC(ds/m) & -0.345 & 0.006 \\
Total Hardness & -0.321 & -0.244 \\
TDS & -0.344 & 0.044 \\
SAR & -0.169 & 0.555 \\
\hline
\end{tabular}

\section{Conclusion}

The groundwater were sampled and analyzed and assessed the water quality for irrigation. Hierarchical cluster analysis is a useful method to group water samples. The indicators to water quality assessment were TDS, $\mathrm{Na}, \mathrm{HCO}_{3}, \mathrm{SO}_{4}, \mathrm{pH}, \mathrm{Cl}$, total hardness, SAR and EC from principal component analysis. The high concentration of $\mathrm{Na}, \mathrm{K}, \mathrm{Ca}, \mathrm{Mg}, \mathrm{HCO}_{3}, \mathrm{Cl}$, and SO4 were correlated with natural environment conditions. The exceed concentration of salts indicated anthropogenic and geologic impact on groundwater. The fuzzy membership and multivariate statistical techniques (HCA, PCA) are the useful and objective methods for water quality evaluations. The reservoir water and deep groundwater can be used for irrigation water but it was required correct management of ground water. Most groundwater were relatively unsuitable for irrigation but it could be used by application of correct management such as removing and reducing the concentrations of $\mathrm{Cl}, \mathrm{SO}_{4}, \mathrm{Na}$ and total hardness in groundwater and also the concentrated deep groundwater was required treatment to reduce the salinity and sodium hazard. Given that irrigation water quality in this area was relatively unsuitable for most agriculture production but pistachio tree was adapted to this area conditions. The integrated management of groundwater for irrigation is the way to solve water quality issues not only in Rafsanjan area, but also in other arid and semi-arid areas. 


\section{References}

Behboudian, M.H., Walker, R.R., Törökfalvy, E., 1986. Effects of water stress and salinity on photosynthesis of pistachio. Scientia Horticulturae 29(3): 251-261.

Deng, X., Huang, J., Rozelle, S., Uchida, E., 2006. Cultivated land conversion and potential agricultural productivity in China. Land Use Policy 23 (4): 372-384.

Freeze, R.A., Cherry, J.A., 1979. Groundwater, Prentice Hall Inc. Englewood Cliffs, New Jersey, USA, 604 pp.

Goldhamer, D.A., 1995. Irrigation management. In: Pistachio Production. Ferguson, L. Beede, R., Teviotdale,B., Weinberger, G., (Eds.), Center for Fruit and Nut Research and Information, Davis, CA. pp.71-81.

Goldhamer, D.A., Phene, B.C., Beede, R., Sherlin, L., Mahan, S., Rose, D., 1987. Effects of sustained deficit irrigation on pistachio tree performance. In: Annual Report, Crop Year 1986-1987., California Pistachio Industry, Fresno, CA. pp. 61-66.

Grieve, C.M., Poss, J.A., Amrhein, C. 2006. Response of Matthiola incana to irrigation with salinity wastewaters. HortScience 41(1): 119-123.

Hosseinifard, S. J., Aminiyan, M. M. 2015. Hydrochemical characterization of groundwater quality for drinking and agricultural purposes: A case study in Rafsanjan plain, Iran. Water Quality, Exposure and Health 7(4): 531-544.

Hosseinifard, S.J., Khademi, H., Kalbasi, M., 2010. Different forms of soil potassium as affected by the age of pistachio (Pistacia Vera L.) trees in Rafsanjan, Iran. Geoderma 155(3-4): 289-297.

Hosseinifard, S.J., Naghavi, H., Eghbal, M.K., Jalalian, A., 2005a. Physiochemical and mineralogical properties of selected soils in the Rafsanjan pistachio area. Iran. $4^{\text {th }}$ International Symposium of Pistachios and Almonds, Tehran, Iran. p. 95.

Hosseinifard, S.J., Rezaee, H., Panahi, B., Ziaeeyan, A., 2005b. Effects of K, Fe and Zn sulfate application on leaf nutrients and nut quality of mature pistachio trees. $4^{\text {th }}$ International Symposium of Pistachios and Almonds, Tehran, Iran. p. 94.

Jang, C.S., Chen, J.S., 2009. Probabilistic assessment of groundwater mixing with surface water for agricultural utilization. Journal of Hydrology 376 (1-2): 188-199.

Karaivazoglou, N.A., Papakosta, D.K., Divanidis, S., 2005. Effect of chloride in irrigation water and form of nitrogen fertilizer on Virginia (flue-cured) tobacco. Field Crops Research 92 (1): 61-74.

Khan, S.h., Tariq, R., Yuanlai, C., Blackwell, J., 2006. Can irrigation be sustainable?. Agricultural Water Management 80(13): 87-99.

Liu, Z., Li, Y., Li, Z., 2009. Surface water quality and land use in Wisconsin, USA - a GIS approach. Journal of Integrative Environmental Sciences 6 (1): 69-89.

Naor, A., 2006. Irrigation scheduling and evaluation of tree water status in deciduous orchards. Horticultural Reviews 32: 111-165.

Ribolzi, O., Cuny, J., Sengsoulichanh, P., Mousquès, C., Soulileuth, B., Pierret, A., Huon, S., Sengtaheuanghoung, $0 ., 2011$. Land use and water quality along a Mekong Tributary in Northern Lao P.D.R. Environmental Management 47(2): 291-302.

Richards, L.A., 1954. Diagnosis Improvement Saline Alkali Soils. United States Department of Agriculture (USDA) Handbook. No. 60. Washington DC, USA. 160p.

Ritcher, B.C., Kreitler, C.W., 1993. Geochemical techniques for identifying sources of ground-water salinization. CRC Press. Boca Raton, FL, USA. 272p

Rogers, P. 1996. America's water: Federal roles and responsibilities. A Twentieth Centruy Fund Book. MIT Press. Cambridge, Massachusetts, London, England. 229p.

Sawyer, N.N., McCarty, P.L., Parkin, G.F., 2003. Chemistry for environmental engineering and science. McGraw-Hill Education, 5th edition, New York, USA. 752p.

Wilcox, L.V., 1955. Classification and use of irrigation waters. United States Department of Agriculture (USDA) Circular No. 939, Washington DC, USA. 19p. 